Research Article

Ahmad Tazay*

\title{
Techno-Economic Feasibility Analysis of a Hybrid Renewable Energy Supply Options for University Buildings in Saudi Arabia
}

https://doi.org/10.1515/eng-2021-0005

Received Jun 18, 2020; accepted Oct 06, 2020

\begin{abstract}
This study presents a detailed feasibility analysis of technical and financial assessment for grid-connected Hybrid Renewable Energy System (HRES) configurations by including grid-only, HRES-only and grid-HRES at four different provinces in the Kingdom of Saudi Arabia (KSA), namely; (Al Baha University, University of Jeddah, Prince Sattam Bin Abdulaziz University, and Tabuk University). The objective of this paper is to search the possibility of supplying the load demand with the optimum system that has the lowest net present cost (NPC) and greenhouse emission $\mathrm{CO}_{2}$. The simulation results show that NPC of a proposed grid/PV system, at the current grid's tariff, is more sufficient than other configurations with a result in a renewable fraction of more than $50 \%$, a payback time of 17 years, and $54.3 \%$ reduction in $\mathrm{CO}_{2}$. The results also show that the integration of $62 \mathrm{~kW}$ PV array with the main grid is the best configuration that leads to the minimum cost of energy (COE) of $0.0688 \$ / \mathrm{kWh}$ and the sell back energy of $9.16 \%$ of total energy consumption at $\mathrm{Al}$ Baha University. Besides, optimization modeling addresses that HRES-only system can supply the full load demand without power shortage $(<0.1 \%)$ with a major contribution from solar PV by $78.5 \%$, wind energy shares $11.3 \%$ of load demand, and $10.2 \%$ from battery banks. The developed analysis concludes that the objective function is feasible for the selected locations. The study has three novelties. Firstly, the required load at different locations of the university's buildings at KSA is supplied by minimizing COE. The objective function is achieved by considering a combination of HRES. Then, it applies the sensitivity analysis for several cases such as payback time, gird's tariff variation, and load demand change. Finally, the current analyses are applicable to any university at KSA and around the world.
\end{abstract}

\footnotetext{
*Corresponding Author: Ahmad Tazay: College of Engineering, Electrical Engineering Department, Al Baha University, Al Aqiq, 65779-7738, Kingdom of Saudi Arabia; Email: afareed@bu.edu.sa
}

๑ Open Access. ( 2021 A. Tazay, published by De Gruyter. (Cc) BY
Keywords: Grid-connected Hybrid Renewable Energy System (HRES), Universities' Educational Buildings at the Kingdom of Saudi Arabia (KSA), Feasibility Analysis, Cost of Energy (COE), Net Present Cost (NPC)

\section{Introduction}

Fossil fuels such as heavy fuel oil, natural gas, diesel oil, and crude oil are the main sources of energy in the Kingdom of Saudi Arabia (KSA). It is one of the top countries in the production and exploration of fossil fuels in the world. In 2012, KSA was ranked as the world's largest oil producer and the second largest oil reserves by 266,455 million barrels of proven oil reserves [1]. Accordingly, more than $75 \%$ of KSA's economy depends on fossil fuels. However, KSA is rated as the largest energy consumer of its own fuel's production. In 2016, KSA was recorded as the world's 10th largest consumer of its total energy from fossil fuels which accounted as $63 \%$ of crude oil and petroleum liquids-based and 37\% of natural gas [2]. In 2018, the King Abdullah Petroleum Studies and Research Center (KAPSARC) reported that more than $70 \%$ of electricity is consumed in residential and commercial sectors as presented in Figure 1 [3]. The increasing demand for energy consumption, according to the population and industry growth,



Figure 1: A sectoral energy consumption in KSA [3]. 
puts more pressure on the economic and environmental sectors of KSA.

British Petroleum (BP) reported that KSA generated 571 Million tons of Carbon dioxide $\left(\mathrm{CO}_{2}\right)$ in 2018 as one of the top producers of greenhouse emissions [4]. Relying on renewable resources instead of fossil fuels has received interesting attention to the government of KSA. On April 25, 2016, the KSA's government announced "Vision 2030" to improve Saudi's economy by depending on renewable resources. The target of producing energy from renewable resources was set to $9.5 \mathrm{GW}$ by the end of 2030. Even renewable resources are available in the Arabian Peninsula, solar and wind energies showed a promising source of nonhydrocarbon energy in the kingdom. A study in [5] indicated that the average daily solar radiation at KSA was varied between 4 to $7.5 \mathrm{kWh} / \mathrm{m}^{2}$. According to SOLARGIS, the



Figure 2: The average global horizontal solar radiance at KSA [6].

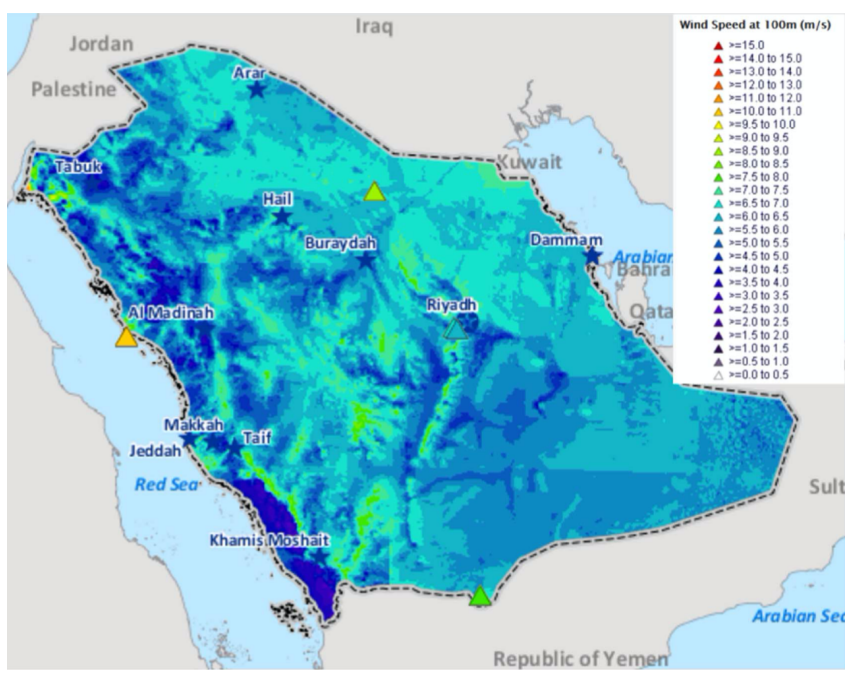

Figure 3: Map of wind speed data at $100 \mathrm{~m}$ in KSA [7]. average annual sum of global horizontal radiation in the Arabian Peninsula is about $2200 \mathrm{kWh} / \mathrm{m}^{2} /$ year as shown in Figure 2 [6]. KSA's wind speed map is shown in Figure 3. It can be clearly seen that KSA has enough wind energy potential with average wind speed 4-8 $\mathrm{m} / \mathrm{s}$ [7]. As can be seen in Figures 2 and 3, the southern region of KSA provides higher solar radiation and wind speed comparing with other provinces. Since, Saudi's electricity generation is governed by fossil fuels, generating energy from renewable resources at commercial and residential buildings will not only reduce the greenhouse emissions in KSA, but will also improve the industrial and economic sectors $[8,9]$.

Several literature studies to explore the performance of solar irradiation and wind speed at KSA have been published recently. Zell et al., summarized one-year solar resource measurements from a monitoring network in $\mathrm{KSA}[10]$. The paper focused on only analyzing the collection of solar resource data without considering other renewable resources at the Arabian Peninsula. The analysis of current and future performance of solar and wind resources was evaluated in [11]. The study concluded that the southern region of KSA has higher daily solar irradiation and wind speed among other regions. The study did not mention the potential for power availability from renewable resources. The potential power generation from solar and wind resources in KSA was analyzed in [12]. The research concludes that wind and solar resources in KSA could generate $50 \mathrm{GW}$ by the end of 2040 . The study by Razmjoo et al. investigated the energy sustainability using off-grid renewable resources for selected cities in Iran until the year 2030 [13]. The study claimed that the investments on renewable energy resources such as solar and wind energy will be economically justified in the Gulf Area. The optimal size of a stand-alone hybrid energy system that enables the minimizing of the cost was implemented by Hossain et al., using renewable resources instead of diesel energy [14]. According to their results, it was verified that renewable resources such as PV, wind, and battery can minimize the cost of energy and reduce greenhouse emission. More optimal and analytical studies need to be explored at different locations at KSA to assess the performance of solar and wind data at KSA.

The techno-economic analysis for grid-connected and off-grid systems at different cities at the Arabian Peninsula and KSA using a combination of HRES such as PV, wind turbine, fuel-cells, and battery were provided in [15-22]. The authors in [15] reviewed the recent control strategies for energy management in hybrid renewable energy system. The paper focused on the energy management strategies used in smart grids for both standalone and grid-connected hy- 
brid renewable energy systems. Razmojoo et al. investigated the energy sustainability of renewable energy at two selected cities at Iran until 2030 [16]. The study concluded that the off-grid system could generate more than $19 \mathrm{kWh}$ annually from solar and wind energies in both cities. Olatomiwa et al. evaluated the economic analysis of six different geo-political villages in [17]. Their simulation results concentrated on the net present costs, cost of energy, and renewable fraction of the PV/Wind/diesel/battery systems. The paper concluded that the PV/diesel/battery hybrid configuration is found as optimum configuration with better performance in fuel consumption and a reduction in $\mathrm{CO}_{2}$ emissions. Another study in [18] implemented economic and technical analysis of solar-wind and diesel system. The study concludes that the optimum hybrid system could generated a required energy and reduce greenhouse emission by integrating $15 \mathrm{~kW}$ PV array, 2 wind turbines, 1 $\mathrm{kW}$ diesel generator, $13,603 \mathrm{~kW}$ of battery, and $1 \mathrm{~kW}$ converter. The potential of supplying the load demand from renewable resources by considering a comparison of various locations at KSA was presented in [19]. The simulation results concluded that the off-grid system at Yanbu city has the minimum COE $(0.609 \$ / \mathrm{kWh})$ by integrating $2 \mathrm{~kW}$ of PV array, $3 \mathrm{~kW}$ of wind turbine, $2 \mathrm{~kW}$ of converter, and 7 battery storage banks with a nominal capacity of 253 Ah. Another study on the west coast of KSA investigated the potential of PV/Wind energy system using HOMER and Matlab [20]. The research concluded that PV energy had more economic features than solar energy with COE of 0.0637 \$/kWh and 0.149 \$/kWh, respectively. Krishna and Al-Talhi investigated the potential of renewable resources at the north region of KSA as comparing with other cities [21]. The paper concluded that Tabuk city in the north region of KSA can generate 110,250 kWh annually from solar energy. The optimization model for an off-grid HRES at the southern region of KSA was analyzed in [22]. The optimization results showed that the lowest COE of the system was $0.289 \$ / \mathrm{kWh}$ which was based on PV/Wind/FC/battery with $176 \mathrm{~kW}$ of PV array, $20 \mathrm{~kW}$ of wind turbines, $98 \mathrm{~kW}$ of fuel cell, and 11 batteries. As in previous studies, they examined the feasibility analysis of residential load without considering the consumed load by commercial and educational buildings at the universities.

The study by Filho et al., highlighted that universities around the world play a significant role in improvement of renewable resources with emphasis on solar energy [23]. The huge engagement of universities to renewable resources has a great potential to reduce energy consumption and carbon emissions. A study in [24] proved that harvesting solar and wind energies instead of fossil fuel can provide more realistic, competitive, and profitable to the kingdom for the next 50 years. The authors in [25] stated that an effective transition from fossil fuels to renewable energy could achieve $70 \%$ of the electricity supply by the year 2032. The economic and technical analysis in [26] in the Gulf area showed the high solar radiation could generate enough energy by integrating the PV array with other resources. However, investment in renewable resources to generate electricity are essential to achieve development in energy sustainability. KSA has more than 38 public and private higher education institutions that are primarily connected to the Saudi Electricity Company of a national grid. Even with the high potential of wind and solar energies in KSA, few projects for renewable resources research have implemented at local universities [27]. Contributing of commercial and educational buildings in consuming energy from renewable resources can achieve the KSA's Vision 2030.

The literature studies for feasibility analysis of implementation of renewable resources at university's buildings are few in KSA or Gulf area. Optimized design and performance of an off-grid for educational building at University of Sharjah, UAE was presented in [28]. The simulation results showed that the developed off-grid renewable energy system could meet the load demand with the best optimization results by sharing $73 \%$ of solar energy, $24 \%$ from the fuel cell, and 3\% from the Diesel generator. Another study in the same area to optimize the size of a grid-connected renewable energy system was examined in [29]. The study concluded that connecting $500 \mathrm{~kW}$ of solar PV capacity of and $100 \mathrm{~kW}$ of fuel cell capacity with the grid lead to lower the cost of energy of $71 \$ / \mathrm{MWh}$, and carbon dioxide emissions of $133 \mathrm{~kg} \mathrm{CO} / \mathrm{MWh}$. The developed system has $40.4 \%$ of renewable fraction and $5 \%$ of the sell back energy to the grid. In [30], a different configuration of renewable resources was investigated using HOMER software at the Engineering Department of Islamic Azad University, Iran. The optimization results showed that the most economical hybrid system was based on wind/diesel/battery hybrid system with nine wind turbines $(20 \mathrm{~kW})$, one diesel generator $(300 \mathrm{~kW}), 50$ batteries, and $50 \mathrm{~kW}$ power converters. The developed system could satisfy 1,174,935 kWh of an annual load demand of the university with net present cost of 4,281,800 $\$$ and cost of energy of $0.285 \$ / \mathrm{kWh}$. As per the author's knowledge, none of the existing work explored the feasibility analysis of educational buildings at KSA's universities. Moreover, there are no articles that compare and analyze the feasibility analysis of different sits of the university's buildings model at KSA. So this lack in the literature about HRES at big public universities for Saudi Arabia motivated the present work. 
This study addresses the following research shortage with regards to grid-connected HRES for an educational building. The study addresses the following issues:

- Can the developed grid-connected HRES be reliable to supply the required load power at university buildings?

- What is the most economically viable of gridconnected HRES systems?

- Can the implementation of HRES reduce the dependence on fossil fuel and greenhouse emissions at KSA by considering the net present cost (NPC) as the foundation of comparison?

- What are the payback time and sensitivity analysis for the optimal HRES configurations?

To answer these questions, the hourly load consumption and weather data are collected for desired locations. The load profile is collected from an educational building at Al Baha University, KSA with a maximum consumption of $20 \mathrm{kWh} /$ day. Then, the meteorological data were collected from KAPSARC and NASA during the years from 2003 to 2018 for the selected universities. The four defined data which include meteorological data, equipment profile, optimization constrains and search space, and load profile are implemented to National Renewable Energy Laboratory's (NERL) Hybrid Optimization of Multiple Electric Renewable (HOMER) as the primary software. The practical cost of each equipment as well as the search space and constrains are defined to find the optimal configuration of the system. The technical and financial analyses are then compared to find optimal system among the desired locations for the project lifetime. The environmental features are then analyzed by comparing different cases. The sensitivity analysis which includes payback time, load variation, grid's tariff is examined using the optimal configuration.

The rest of the paper is organized as follows. Section 2 provides the resources analysis and meteorological data of the selected locations. Section 3 addresses the mathematical models of the developed system. It also indicates the economic equations and detailed specification data of each system's component. Section 4 examines the de- veloped system by applying optimizations and sensitivity analysis. The conclusion and remarks are provided in Section 5.

\section{Resource Analysis}

Analysis of the available resource at the selected universities of KSA includes solar radiation, wind speed, and temperature data. Four public universities are selected to investigate the practical data availability as marked in Figure 4. The weather data are an important factor that impacts the size of the system's component. The meteorological data for the selected universities are obtained from NASA website and King Abdullah City for Atomic and Renewable Energy KACARE [7, 31]. Table 1 summarized the weather data and location of each considered university. It also shows the daily average solar radiation and wind speed. The average annual temperature of each considered location is also provided in Table 1. The detailed monthly meteorological data for the selected universities are given in the following subsections.

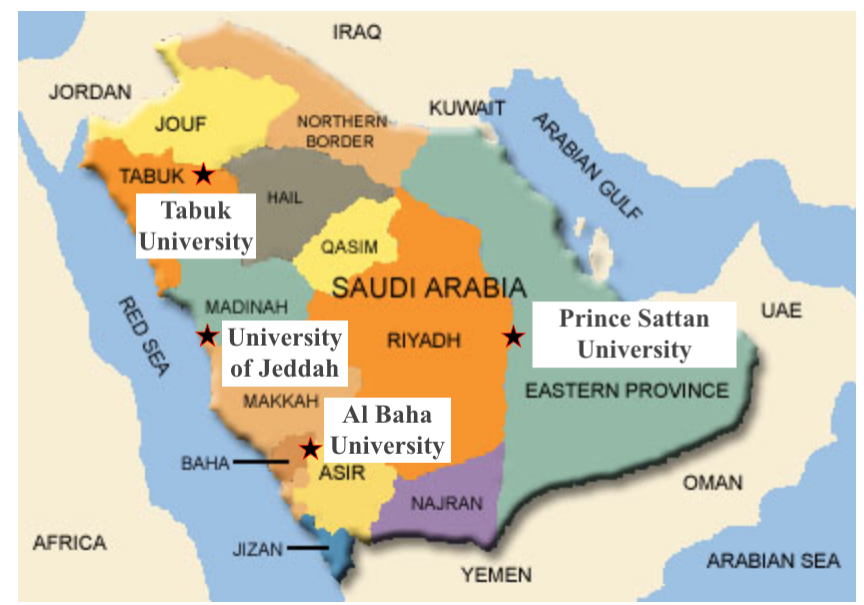

Figure 4: Map of the four considered universities at KSA.

Table 1: Meteorological data of the selected universities.

\begin{tabular}{|c|c|c|c|c|c|}
\hline Univ. & & e & Solar & Wind & Temp. \\
\hline AlBaha & $20^{\circ} 11^{\prime} \mathrm{N}$ & 4 & 6.13 & 5.01 & 25.16 \\
\hline & & & 4 & 66 & .97 \\
\hline & & $\mathbf{E}$ & .72 & 4.88 & 26.59 \\
\hline Tabuk/northern & $28^{\circ} 39^{\prime} \mathrm{N}$ & $36^{\circ} 47^{\prime} \mathrm{E}$ & 5.86 & 5.25 & 21.38 \\
\hline
\end{tabular}




\subsection{Solar Radiation Data}

The variation of monthly average solar energy of the four different locations is given in Figure 5. It indicates the peak solar radiation during the summer season while it decreases in winter months. It can be clearly seen that Tabuk University has a monthly peak solar radiation with almost $8.27 \mathrm{kWh} / \mathrm{m}^{2}$. Sattam University shows the lowest solar irradiation with almost $3.47 \mathrm{kWh} / \mathrm{m}^{2}$ as presented in Figure 5. Al Baha University has the highest average solar radiation per year with $6.13 \mathrm{kWh} / \mathrm{m}^{2}$ while Sattam University has the lowest average solar radiation by $5.72 \mathrm{kWh} / \mathrm{m}^{2}$. The average monthly solar radiation plays a key rule in sizing the PV array.

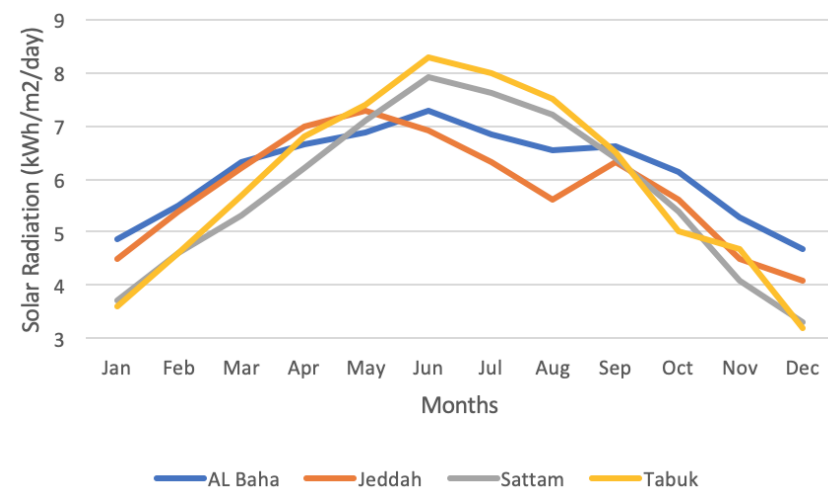

Figure 5: Monthly solar irradiation at the selected universities.

\subsection{Wind Speed Data}

The variation of monthly average wind speed of the four different locations is given in Figure 6. It is also recognized that the wind speed is high at the desired universities

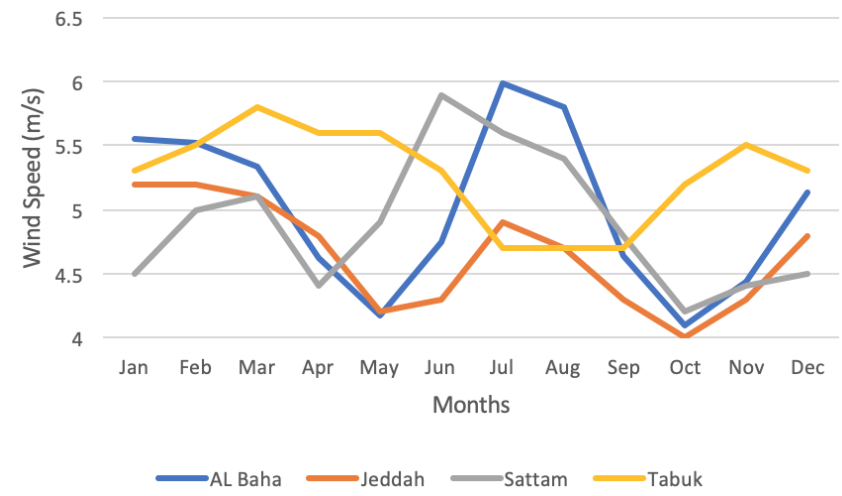

Figure 6: Monthly average wind speed at the selected universities. from June to August. University of Jeddah shows approximately the minimum monthly average wind speed while Al Baha University has the highest wind speed among the other universities. Tabuk University has the highest average monthly wind speed while University of Jeddah has the lowest wind speed over the tested year.

\subsection{Temperature Data}

Temperature recording is important in monitoring the performance of the installed system. It affects the output energy from PV array and wind turbine. Figure 7 shows the average monthly temperature of the four universities. University of Jeddah is warmer than other universities while Tabuk University is the coldest one. The variation of weather data across the selected locations affects the optimal size of the system's components which leads to different combinations of the system resources. It also impacts the cost analysis of each system.
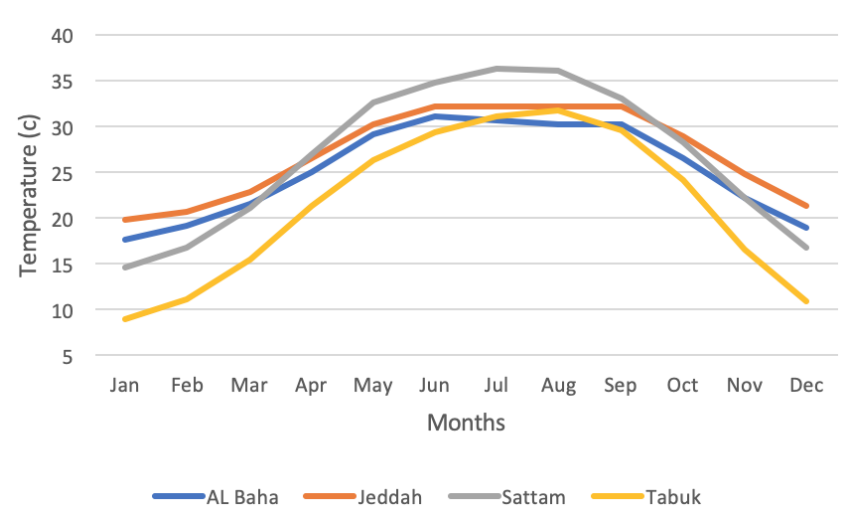

Figure 7: Monthly average temperature at the selected universities.

\section{System Configuration and Model}

\subsection{System Structure}

The grid-connected HRES system consists of a PV array, DC/AC converter, wind turbine (WT), and battery bank. The HRES is designed based on the schematic diagram as shown in Figure 8. Each component of the system is optimized based on the different meteorological data at the considered locations. The WT and PV array generate the available energy to meet the load demand while the excess energy is used for charging the energy storage or injected 


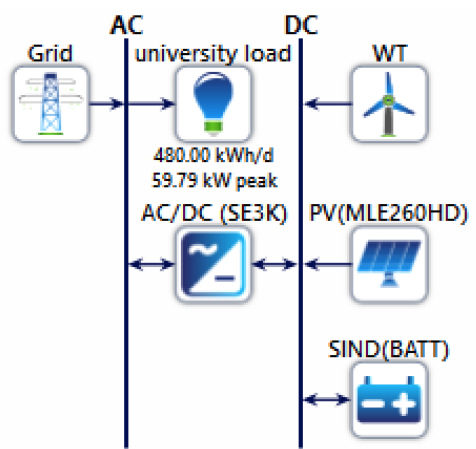

Figure 8: Schematic diagram of the grid-connected HRES system.

back to the main grid. The detailed analysis and mathematical model of each component are presented in this study.

\subsection{Mathematical Model}

This section provides the mathematical model of the HRES includes the technical model of PV, WT, DC/AC converter, and battery bank. It also provides the economic model of different configurations of the grid-connected HRES system. The developed system in Figure 8 is used for investigating the mathematical models.

\subsubsection{Photovoltaic Model}

The main objective of solar panels is into convert solar energy to electrical ones. Two types of solar energy have been commercially implemented which are categorized into the photovoltaic solar panel (PV) and concentrated solar power (CSP). PV technology is used in this paper because of its possibility to be installed at the university's campus. The PV panel absorbs energy from the sun's photon using a photodiode and converts it to electric energy. A typical PV system consists of PV array, power electronics, and battery storage. Since the PV system is connected to the main grid, energy storage may be neglected. The reason is that energy storage is costly, and its lifetime is limited by comparing it with other components of the system.

The PV consists of several diodes which form a single cell. The mathematical equation of a single diode can be obtained from the Shockley equation as follow [32]:

$$
I_{P V}=I_{p h}-I_{s a t}\left[e^{\frac{V_{P V}+R_{s} I_{P V}}{V_{t}}-1}\right]-\frac{V_{P V}+R_{S} I_{P V}}{R_{p}}
$$

where; $I_{P V}, I_{p h}$, and $I_{s a t}$ are the rated currents of cell, photon, and diode reverse saturation currents (A); respectively. The voltages $V_{P V}$ and $V_{t}$ are the rated cell and thermal volt- ages (V); respectively. The series and parallel resistance are $R_{S}$ and $R_{P}(\Omega)$. The thermal voltage, photon current, and reverse saturation current of a single diode are given as [33]:

$$
\begin{gathered}
V_{t}=\frac{n k T}{q} \\
I_{p h}=I_{p h}\left(T_{1}\right)\left(1+K_{o}\left(T-T_{1}\right)\right) \\
I_{p h}\left(T_{1}\right)=\frac{G I_{s c\left(T_{1, n o r m}\right)}}{G_{n o r m}} \\
K_{s a t}=\frac{I_{s c\left(T_{2}\right)}-I_{s c\left(T_{1}\right)}}{T_{2}-T_{1}} \\
\left.I_{s a t\left(T_{1}\right)}\left(\frac{T}{T_{1}}\right)^{\frac{3}{n}} e^{-\left[\frac{q V g}{n k}\left(\frac{1}{T}-\frac{1}{T_{1}}\right)\right.}\right] \\
I_{s a t\left(T_{1}\right)}=\frac{I_{s c\left(T_{1}\right)}}{\left(e^{\frac{q V_{O C}\left(T_{1}\right)}{n k T_{1}}}\right)-1} \\
R_{s}=-\frac{d_{v}}{d I_{V O C}}-\frac{1}{X_{V}} \\
X_{V}=I_{s a t\left(T_{1}\right)} \frac{q}{n k T_{1}} e^{\frac{q V_{O C} T_{1}}{n k T_{1}}}
\end{gathered}
$$

where; $T$ is a temperature in Kelvin $\left(\mathrm{T}=\mathrm{C}^{\circ}+273.16\right) ; k$ is Boltzmann constant $\left(1.38 \times 10^{-23}\right)(\mathrm{J} / \mathrm{k}) ; n$ is ideality coefficient (value between 1 to 2); $q$ is charge of electron $\left(1.6 \times 10^{-19}\right)(C) ; G$ is solar irradiation $\left(\mathrm{kWh} / \mathrm{m}^{2}\right) ; I_{s c}$ is short circuit current (A); $V_{O C}$ open circuit voltage $(\mathrm{V}) ; K_{o}$ is a rated constant of $I_{S c}$ at $T ; T_{1}$ and $T_{2}$ are different temperatures, $R_{S}$ is the series resistance $(\Omega)$. All constants can be calculated from the datasheet of PV array's manufacture. The output power of PV system can be calculated using the solar radiation for the number of PV panels $N_{P V}$ as follows:

$$
P_{P V}=N_{P V} I_{P V} V_{P V}
$$

\subsubsection{Wind Turbine Model}

The WT converts the kinetic energy into electrical energy. Wind energy has a high energy conversion comparing with other renewable resources. However, the initial cost and weather restriction limits the harvesting of wind energy. The output power from WT is measured as [34, 35]:

$$
P_{W T}=N_{W} \mu_{W} P_{W}
$$




$$
P_{W T}=N_{W}\left(\frac{1}{2} C_{p}(\lambda, \beta) \rho A v_{r}{ }^{3}\right)
$$

where; $N_{W}$ is the number of WT; $\rho$ is the air density $\left(\mathrm{kg} / \mathrm{m}^{3}\right) ; \mu_{W}$ is the WT's efficiency; $C_{p}(\lambda, \beta)$ is the power coefficient at the tip speed ratio of the rotor and blade pitch angle; A is the WT area $\left(\mathrm{m}^{2}\right) ; v_{r}$ is the rated wind speed $(\mathrm{m} / \mathrm{s})$.

The mechanical output power depends on the operational wind speed. The WT can be operated in a range between lower cut-in wind speed and higher cut-out wind speed. The rated output power of WT $\left(P_{W T}^{r}\right)$ is fixed at rated wind speed. On the other hand, when the wind speed is varied between the rated speed and cut-in speed, the WT is operated as variable rotor speed. So, the different scenarios of the average wind power can be expressed as a function of wind speed as follows:

$$
P_{W T}^{a v}= \begin{cases}\frac{1}{2} C_{p}(\lambda, \beta) \rho A v_{r}{ }^{3} & \text { if } v_{c u t-i n} \leq v_{r} \\ \left(P_{W T}^{r}\right) & \text { if } v_{r} \leq v_{c u t-o u t} \\ 0 \text { otherwise } & \end{cases}
$$

\subsubsection{Battery Bank Model}

Storage devices are the key to operating a hybrid system. Different storage devices have been used in researches and industries such as batteries, fuel cells, and freewheel. Since energy storage represents a big share in the total cost of the system, many grid-connected systems ignore the energy storage devices for economical purposes. Considering the cost of the system, battery among other energy storage is used in the hybrid system for its economic advantages. The operational energy of battery storage requires careful attention in order to increase the battery's lifetime and efficiency. The charging and discharging of the battery should be limited within the maximum and minimum energy level requirements. The battery's energy capacity during charging period when the output generated power of the system is greater than the load demand as [36]:

$$
E_{B}(t)=E_{B}(t-1)(1-\sigma)+\left(P_{\text {sys }}(t)-\frac{P_{L}(t)}{\mu \operatorname{con} v}\right) \mu_{B}
$$

The battery's energy capacity during discharging mode when the load demand is higher than the output generated power of the system, can be expressed as:

$$
E_{B}(t)=E_{B}(t-1)(1-\sigma)+\left(\frac{P_{L}(t)}{\mu_{c o n v}}-P_{s y s}(t)\right)
$$

where; $E_{B}(t)$ is the battery's energy capacity as a function of time (kWh); $P_{s y s}(t)$ is the total generated power from the HRES (kW); $P_{L}(t)$ is the load's power demand $(\mathrm{kW}) ; \sigma$ is the self-discharge rate of the battery bank per hour; $\mu_{B}$ is battery's efficiency; $\mu_{\text {conv }}$ is DC/AC converter's efficiency which can be calculated from Equation (15).

\subsubsection{DC/AC converter Model}

A power electronic converter is an important device to achieve the load's requirement. Since the HREs generates DC energy to the grid, the output energy is converted into $\mathrm{AC}$ using power electronic devices. The DC/AC converter is required for the PV system, WT, and battery. The conversion efficiency of the DC/AC converter is calculated using quadratic interpolation of an experimental curve as [37]:

$$
\mu_{\text {conv }}=1-\frac{1}{N}\left(0.0094+0.043 \times N+0.04 \times N^{2}\right)
$$

where; $N$ is the normalized power of DC/AC converter (W).

\subsubsection{Electric Grid}

The electric grid is the main source of energy to the university's campuses. As mentioned before, the commercial and residential buildings consume more than $70 \%$ of the total electric generation in KSA. This huge energy consumption puts more pressure on the main grid. The grid-connected HRES system can provide advantages such as reliability and efficiency as well as selling excess energy to the main grid. So, the load can be partially supplied from the grid while the energy from HRES provides the required load. The current tariff of electricity from the main grid is 0.085 $\$ / \mathrm{kWh}$ which makes fossil fuel cheaper than other renewable resources. However, the tariff is expected to increase regarding to unexpected price of fossil fuel fluctuation. The flat-rate tariff of the grid's energy for commercial and governmental buildings is $0.085 \$ / \mathrm{kWh}$ while the sell back rate is $0.05 \$ / \mathrm{kWh}[38,39]$. Since the system partially depends on the energy from the main grid, the energy dependency on the grid can be minimized as well as the cost of energy can be reduced.

\subsubsection{Load Profile}

A load of desired universities depends on the main grid. The same load profile is assumed to be used for the selected locations. The purpose of this approach is to apply a feasibility analysis based on weather data and available resources for different locations. The average daily energy of the loads is shown in Figure 9. The building of three lev- 
els in the faculty of electrical engineering at Al Baha University is selected to exam the feasibility of grid-connected HRES. The building consists of ten laboratories, six lecture rooms, and ten faculty offices. The energy consumption of electricity is mainly shared by air-conditioning, lighting, and laboratory equipment. The average energy demand is about $480 \mathrm{kWh} /$ day while the daily average load is $20 \mathrm{KW}$. Figure 9 shows that the daily peak load occurs from 8 to 4 during the regular education session which determines the size of the system. The monthly load profile is given in Figure 10 with a peak load is about $60 \mathrm{KW}$.

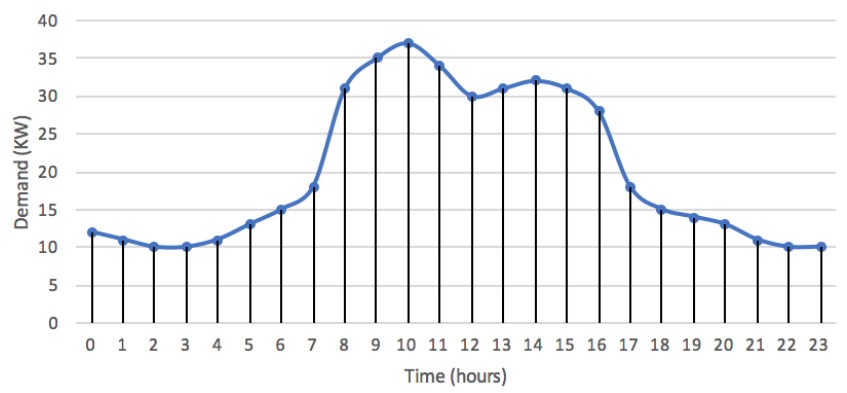

Figure 9: Energy load demand for 24-hour period, educational building, Al Baha University.

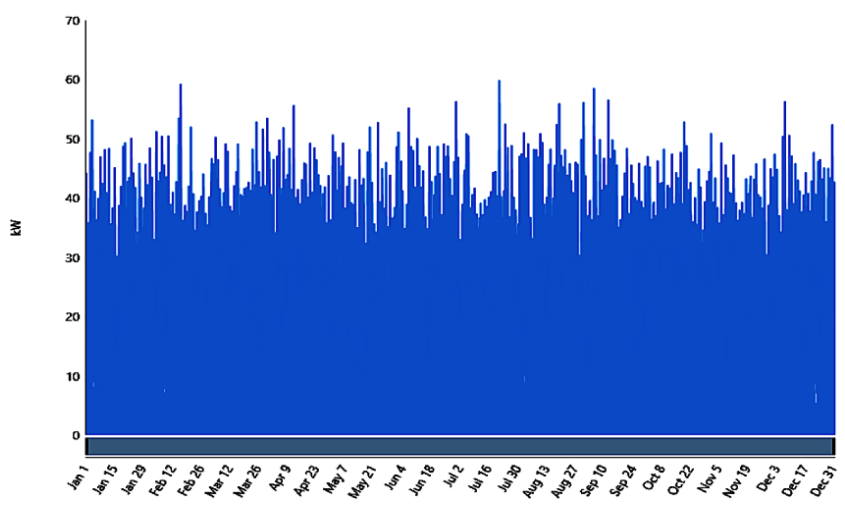

Figure 10: yearly load demand at the selected location.

\subsection{Economic Model}

\subsubsection{Economic Equations}

The economic model is used for assessing the total cost of the developed systems. The NPC is the difference between the total cost of installation and operation of the system and the total earned revenues over the project lifetime.
NPC and capital recovery are calculated based on the following equations [41, 43]:

$$
\begin{aligned}
\operatorname{NPC}(\$) & =\frac{T A C}{\operatorname{CRF}\left(i, R_{p r j}\right)} \\
\operatorname{CRF}(\$) & =\frac{i \times(1+i)^{N}}{(1+i)^{N}-1} \\
i & =\frac{i^{\prime}-f}{1+f}
\end{aligned}
$$

where; TAC is the total annualized cost (\$); $C R F$ is the capital recovery factor; $R_{p r j}$ is the annual project lifetime; $N$ is the number of years; $i$ is the annual real interest rate (\%); $i$ 'is the nominal interest rate which equals $6 \%$ in the proposed system; $f$ is the annual inflation rate which equals $3 \%$. The $C O E$ is the average cost of used generated energy from HRES in $\$ / \mathrm{kWh}$. It can be expressed as:

$$
\operatorname{COE}(\$)=\frac{T A C}{E_{\text {total }}}
$$

where, $E_{\text {total }}$ is total energy consumption in $\mathrm{kWh} /$ year. The energy contribution from renewable energy resources of grid-connected HRES is called renewable fraction (RF). It measures the percentage of energy contribution from renewable resources comparing to the total energy of the system. Each energy resources of grid-connected HRES generates a fraction of energy based on its capacity and cost manners. The RF can be expressed as:

$$
\begin{gathered}
R F_{H R E S}(\%)=\frac{E_{H R E S}}{E_{\text {total }}} \\
E_{\text {total }}=E_{\text {grid }}+E_{\text {HRES }}
\end{gathered}
$$

\subsubsection{Components Prices}

The PV array consists of a combination of series and parallel panels. The PV installation and replacement cost may vary between $1000 \$ / \mathrm{kW}$ to $3000 \$ / \mathrm{kW}$. So, the installation and operation \& maintenance are $1700 \$ / \mathrm{kW}$ and 10 $\$$ /year; respectively. The detailed data of the $\mathrm{PV}$ is given in Table A10.

The three-phase WT with an ac induction generator is used in simulation results. The installation fees are 3,000 $\$ / \mathrm{kW}$ while the replacement cost is $2500 \$ / \mathrm{kW}$. The lifetime of WT is 20 years. The operation \& maintenance cost is assumed to be $100 \$$ /year which includes the maintenance and cleaning of WT. Table A11 shows the data and characteristics of the selected WT. 
Table 2: economical cost of the grid-connected HRES system.

\begin{tabular}{lccccc}
\hline System & Installation $(\$)$ & Replacement $(\$)$ & O\&M (\$/year) & Lifetime (year) & Fuel $(\$ / \mathrm{kWh})$ \\
\hline PV & 1700 & 1700 & 10 & 25 & 0 \\
WT & 3000 & 3000 & 100 & 20 & 0 \\
Battery & 325 & 325 & 50 & 8 & 0 \\
Converter & 300 & 275 & 0 & 12 & 0 \\
Grid & 0 & 0 & 0 & $\infty$ & 0.085 \\
\hline
\end{tabular}

The lead-acid battery is selected instead of lithiumion because of the economical cost. The capital cost of the battery is $325 \$$ /unit and the replacement cost is estimated to be $325 \$ /$ unit. The O\&M costs are estimated to be $50 \$ /$ unit/year for watering and cleaning the battery banks. The data of battery banks are given in Table A12.

The price of DC/AC converters is low compared with other components of the system. The current efficiency of the $\mathrm{DC} / \mathrm{AC}$ converter is about $98 \%$ with a lifetime to be 12 years. The installation and replacement costs are $300 \$ / \mathrm{kW}$ and $275 \$ / \mathrm{kW}$, respectively. The cost of operation and maintenance is $10 \$ /$ year which includes regulating and cleaning of the device. The converter's data is provided in Table A13. The cost summary of the system is given in Table 2. It also shows the economic cost of each component of the HRES system as well as the main grid. The detailed economic and technical data of each component are given in the Appendix section.

\section{Simulation and Results}

The HRES system is connected to the main grid to supply the required load demand. Five different combinations of developed systems are simulated for four selected locations. At each selected location, the system's configurations are examined to find the minimum NPC that includes grid-connected HRES includes grid-only, HRES-only, and a combination of grid-connected RES. The load profile, meteorological restriction, optimization constraints, and monetary data are used to computer-aided renewable energy simulation tool (HOMER) to analyze feasibility and sensitivity study of the systems. The simulation results have been separated into two categories which include optimization results and sensitivity analysis results.

The goal of the simulation procedure is to find the optimal configuration of the system that satisfies the load demand with minimum NPC. It also investigates the renewable energy potential at each selected location for compar- ison purposes. The search space and constraints of the objective function are selected based on the following steps:

- The range of the PV array is varied from 0 to $260 \mathrm{~kW}$.

- The size of the battery bank is varied from 0 to 500 units of batteries.

- The DC/AC converter is selected from 1 to $100 \mathrm{KW}$.

- The size of WT is varied from 0 to $180 \mathrm{~kW}$.

- The penetration of renewable resources is more than $30 \%$.

- The load demand is identical for all desired locations.

- The project's life time is set to 25 years.

A flowchart of the optimization process for different universities using HOMER software is given in Figure 11. The four input data are used at each selected location which contain daily load demand, meteorological conditions, economic and sizing of components, and project constraints. The HOMER software finds the optimal configurations based on minimizing the objective function and subject to defined constraints by minimizing the objective function using Graham Algorithm [42]. The optimal configurations are achieved when the system meet the load demand. The sensitivity analysis is also applied for each developed system to assess the impact of uncertain parameters on the optimal results. The previous methodology is repeated for each location to compare the final results. The assessment and optimization for sizing of the feasibility of the grid-connected HRES are carried out via the following steps:

1. Gather the required weather data and load profile of the selected universities by including solar radiation, wind speed, temperature, and daily load demand.

2. Define optimization constrains the objective function.

3. Set economic feature and search number of each component.

4. Solve the objective function using HOMER software by minimizing NPC. 


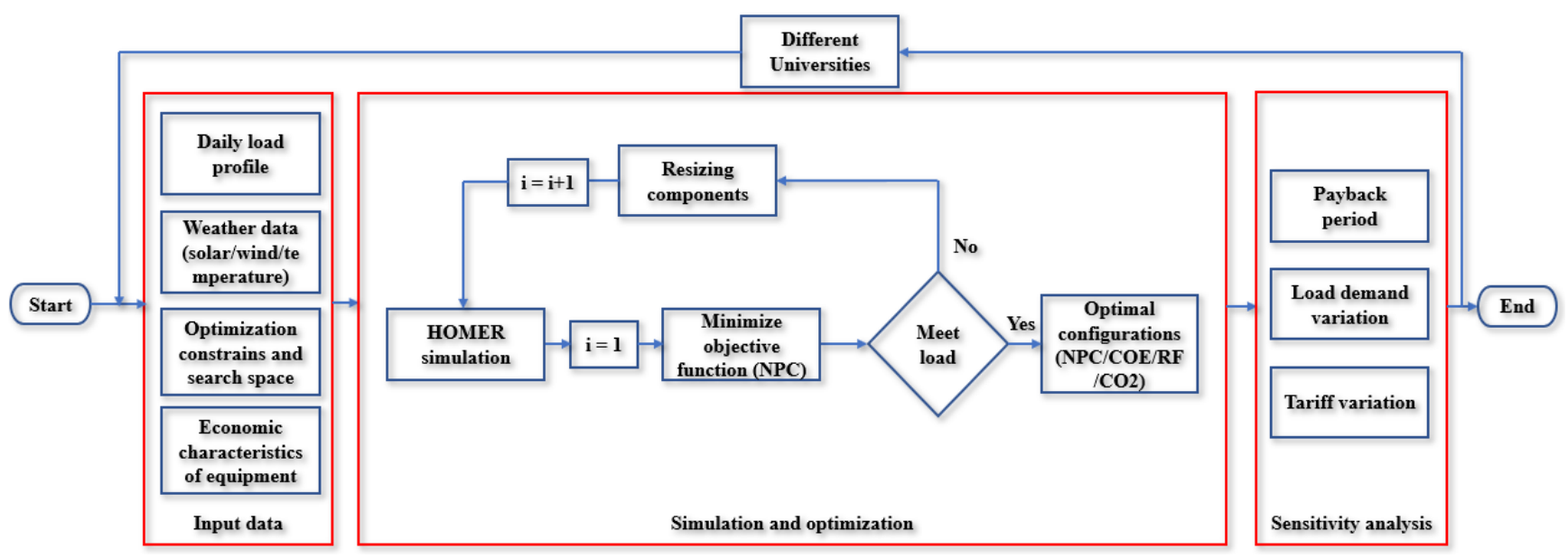

Figure 11: A flowchart of the optimization technique using HOMER simulation.

5. Present the output optimal system that meets the load demand.

6. Apply sensitivity analysis for the developed system by performing payback period, load variation, and tariff variation.

7. Repeat the previous process for different university buildings.

\subsection{Optimization Results}

\subsubsection{Grid-only System}

The main grid covers the full load demand where RF is almost $0 \%$. The total NPC is accounted from the main grid which is calculated as 234,585 \$ over the 25 -project lifetime. A total purchased energy from the main grid is 175,200 $\mathrm{kWh} /$ year at the assigned electricity's tariff which includes the operational cost and fossil fuel prices. The harmful emission of $\mathrm{CO}_{2}$ is $110,748 \mathrm{~kg} /$ year for all selected locations based on the assigned load. The harmful emission is set as $632 \mathrm{~g} / \mathrm{kWh}$ of Carbon Dioxide, $1.79 \mathrm{~g} / \mathrm{kWh}$ of Carbon Monoxide, $0.2 \mathrm{~g} / \mathrm{kWh}$ of Unborned Hydrocarbons, 0.14 $\mathrm{g} / \mathrm{kWh}$ of Particular Matter, $1.47 \mathrm{~g} / \mathrm{kWh}$ of Sulfur Dioxide, and $1.60 \mathrm{~g} / \mathrm{kWh}$ of Nitrogen Oxides [43].

\subsubsection{Grid-connected HRES System}

The search space of the HRES system is varied based on the assigned constraints in previous sections. The technical and economic optimization for all cases and locations are given in Tables 3, 4, 5, and 6. The total energy production from the HRES system is varied from $181,712 \mathrm{kWh} /$ year to $255,285 \mathrm{kWh} /$ year while the $\mathrm{RF}$ is more than $30 \%$ in all cases. The $\mathrm{CO}_{2}$ emission is varied from $43,627 \mathrm{~kg} /$ year to $80,055 \mathrm{~kg} /$ year in all cases. Since the simulation results of the Grid-only system show that the $\mathrm{CO}_{2}$ emission is 110,748 $\mathrm{kg} /$ year, the integration of HRES provides a significant reduction of greenhouse gas emission comparing with grid only system. It can be recognized that Grid/PV/WT system can provides a high $\mathrm{RF}$ value and low $\mathrm{CO}_{2}$ emission.

The best configuration of the simulation process is selected based on the one that has minimum COE and NPC while the annual load demand shortage is less than $0.1 \%$. It can be recognized from the optimization results that the combination Grid/PV has the minimum COE for all selected universities. The summarized results at Tables 4 to 7 indicate that the integration of the PV system to the main grid can achieve the lower NPC and COE as well as reduce $\mathrm{CO}_{2}$ emission.

The results show that for Al Baha University (Table 4), Grid/PV system has the minimum COE of $0.0688 \$ / \mathrm{kWh}$ with $62 \mathrm{~kW}$ PV array and $47 \mathrm{~kW} \mathrm{AC/DC} \mathrm{converter.} \mathrm{The} \mathrm{pro-}$ posed system can minimize $54.3 \%$ of $\mathrm{CO}_{2}$ comparing with the grid-only system. The renewable fraction (RF) of the selected system is $59.1 \%$ which indicates less $\mathrm{CO}_{2}$ emission and energy from the grid. The proposed system at $\mathrm{Al}$ Baha University can produce $197,315 \mathrm{kWh}$ /year while the sell back energy is $17,665 \mathrm{kWh}$ /year which represents $9.16 \%$ of total energy consumption. The proposed system can produce 117,271 kWh/year from PV system while the purchase energy from the grid is $80,044 \mathrm{kWh} /$ year. The exceeded energy from the system is $2,147 \mathrm{kWh} /$ year which accounted as $1.09 \%$ of the total produced energy.

In University of Jeddah, the Grid/PV system results in the lower COE comparing with other cases with 0.0702 $\$ / \mathrm{kWh}$ and the combination was $60 \mathrm{~kW} \mathrm{PV}$ array and 
Table 3: Brief comparison of related studies.

\begin{tabular}{|c|c|c|c|c|c|c|}
\hline Investigators-year & Location & $\begin{array}{l}\text { System } \\
\text { studied }\end{array}$ & Technique & $\begin{array}{c}\mathrm{COE} \\
(\$ / \mathrm{kWh})\end{array}$ & $\begin{array}{l}\mathrm{RF} \\
(\%)\end{array}$ & $\begin{array}{c}\mathrm{CO}_{2} \\
(\mathrm{~kg} / \mathrm{y})\end{array}$ \\
\hline Ref. [24]-2019 & Uni. of Sharjah, UAE & PV/FC/Battery/Diesel/Grid & Techno-economic & 0.092 & 66.1 & 24,000 \\
\hline Ref. [25]-2019 & Uni. of Sharjah, UAE & $\mathrm{PV} / \mathrm{FC} / \mathrm{Grid}$ & Economic-environment & 0.071 & 40.4 & 133,000 \\
\hline Ref. [26]-2017 & Islamic Azad Uni., Iran & PV/WT/Battery/Diesel & Techno-economic & 0.319 & 100 & 1,034 \\
\hline Current-2020 & Al Baha Uni., KSA & Grid/PV & Feasibility-Sensitivity & 0.069 & 59.1 & 50,588 \\
\hline
\end{tabular}

Table 4: Optimization results of grid-connected HRES systems for Al Baha University.

\begin{tabular}{|c|c|c|c|c|c|c|c|c|c|}
\hline System & $\mathrm{PV}(\mathrm{kW})$ & WT(kW) & $\mathrm{AC} / \mathrm{DC}(\mathrm{kW})$ & $\operatorname{COE}(\$ / \mathrm{kWh})$ & $\mathrm{NPC}(\$)$ & $\mathrm{RF}(\%)$ & Prod.(kWh/y) & Cons.(kWh/y) & $\mathrm{CO}_{2}(\mathrm{~kg} / \mathrm{y})$ \\
\hline Grid/PV & 62 & 0 & 47 & 0.0688 & 260,812 & 59.1 & 197,315 & 192,865 & 50,588 \\
\hline Grid/WT & 0 & 96 & 60 & 0.107 & 406,997 & 30.2 & 199,027 & 194,559 & 80,055 \\
\hline Grid/PV/WT & 65 & 21 & 54 & 0.0707 & 280,935 & 66.2 & 206,421 & 202,101 & 43,627 \\
\hline
\end{tabular}

Table 5: Optimization results of grid-connected HRES systems for University of Jeddah.

\begin{tabular}{|c|c|c|c|c|c|c|c|c|c|}
\hline System & $\mathrm{PV}(\mathrm{kW})$ & WT(kW) & $A C / D C(k W)$ & $\operatorname{COE}(\$ / \mathrm{kWh})$ & $\mathrm{NPC}(\$)$ & $\mathrm{RF}(\%)$ & Prod.(kWh/y) & Cons.(kWh/y) & $\mathrm{CO}_{2}(\mathrm{~kg} / \mathrm{y})$ \\
\hline Grid/PV & 60 & 0 & 45 & 0.0702 & 262,927 & 56.7 & 194,994 & 190,575 & 52,183 \\
\hline Grid/WT & 0 & 144 & 60 & 0.124 & 487,863 & 37.7 & 210,832 & 199,747 & 78,597 \\
\hline Grid/PV/WT & 62 & 12 & 43 & 0.0735 & 276,775 & 59.9 & 199,450 & 191,646 & 48,534 \\
\hline
\end{tabular}

Table 6: Optimization results of grid-connected HRES systems for Sattam University.

\begin{tabular}{|c|c|c|c|c|c|c|c|c|c|}
\hline System & $\mathrm{PV}(\mathrm{kW})$ & WT(kW) & $\mathrm{AC} / \mathrm{DC}(\mathrm{kW})$ & $\operatorname{COE}(\$ / \mathrm{kWh})$ & $\mathrm{NPC}(\$)$ & $\mathrm{RF}(\%)$ & Prod.(kWh/y) & Cons.(kWh/y) & $\mathrm{CO}_{2}(\mathrm{~kg} / \mathrm{y})$ \\
\hline Grid/PV & 55 & 0 & 40 & 0.0753 & 272,352 & 50.1 & 187,713 & 183,988 & 58,060 \\
\hline Grid/WT & 0 & 162 & 60 & 0.120 & 496,158 & 45.1 & 230,660 & 209,874 & 72,820 \\
\hline Grid/PV/WT & 43 & 9 & 32 & 0.0806 & 282,062 & 43.7 & 181,712 & 177,919 & 63,321 \\
\hline
\end{tabular}

$45 \mathrm{~kW} \mathrm{AC/DC} \mathrm{converter.} \mathrm{The} \mathrm{developed} \mathrm{system} \mathrm{produces}$ $52,183 \mathrm{~kg} /$ year of $\mathrm{CO}_{2}$ with $\mathrm{RF}$ of $56.7 \%$ as represented in Table 4. The total load of the Grid/PV configuration at University of Jeddah consumes 190,575 kWh/year which divided into $175,200 \mathrm{kWh} /$ year for ac load (91.9\%) and 15,375 $\mathrm{kWh} /$ year (8.07\%) as injected energy back to the grid. The purchased energy from the grid is $82,568 \mathrm{kWh} /$ year while the excess electricity is $2,215 \mathrm{kWh} /$ year.

The developed Grid/PV in Table 6 presents the lowest COE at Sattam University comparing with other configurations. The COE of the system is $0.0753 \$ / \mathrm{kWh}$ with the sizing of $55 \mathrm{~kW}$ PV array and $40 \mathrm{~kW} \mathrm{AC/DC} \mathrm{converter.} \mathrm{The} \mathrm{PV}$ array shares $50.1 \%$ of the load and the system generates $58,060 \mathrm{~kg} /$ year of $\mathrm{CO}_{2}$. The system can generate 187,713 $\mathrm{kWh}$ and the grid purchase is $91,868 \mathrm{kWh}$ per year. The total energy consumption is $183,988 \mathrm{kWh} /$ year while the annual sell back energy is $8,788 \mathrm{kWh} /$ year $(4.78 \%)$.

In Tabuk University the north region of KSA, the simulation results show that Grid/PV configuration represents a low COE with $0.0714 \$ / \mathrm{kWh}$ with sizing of $58 \mathrm{~kW}$ PV array and $44 \mathrm{~kW} \mathrm{AC/DC} \mathrm{converter.} \mathrm{The} \mathrm{renewable} \mathrm{fraction} \mathrm{of}$ the selected system is $54.8 \%$ with 53,981 of $\mathrm{CO}_{2}$. The pro- posed system at Al Tabuk University can produce 192,943 $\mathrm{kWh} /$ year and purchases $85,413 \mathrm{kWh} /$ year from the grid. The consumed load is $175,200 \mathrm{kWh}$ while the sell back power to the grid is $13,784 \mathrm{kWh} /$ year $(7.29 \%)$.

\subsubsection{HRES-only System}

The HRES covers the load demand where the grid is disconnected. The optimal size and NPC of the system with the lowest COE are given in Table 7. The total energy production from HRES systems are varied from 706,958 $\mathrm{kWh}$ to $474,761 \mathrm{kWh}$ while the energy consumption is almost equal. It can be seen from Table 7 that the NPC is significantly increased to cover the load demand comparing with other combinations of the grid-connected-HRES systems. The NPC of developed HRES-only system at Al Baha University is lower than other locations because of high solar radiation and wind speed in this area. The proposed configurations can meet the load demand with no load shortage. So, the proposed system can be implemented for an off-grid situation with high economic consideration. 
Table 7: Optimization results of grid-connected HRES systems for Tabuk University.

\begin{tabular}{|c|c|c|c|c|c|c|c|c|c|}
\hline System & $\mathrm{PV}(\mathrm{kW})$ & WT(kW) & $\mathrm{AC} / \mathrm{DC}(\mathrm{kW})$ & $\operatorname{COE}(\$ / \mathrm{kWh})$ & $\mathrm{NPC}(\$)$ & RF(\%) & Prod.(kWh/y) & Cons.(kWh/y) & $\mathrm{CO}_{2}(\mathrm{~kg} / \mathrm{y})$ \\
\hline Grid/PV & 58 & 0 & 44 & 0.0714 & 265,273 & 54.8 & 192,943 & 188,984 & 53,981 \\
\hline Grid/WT & 0 & 162 & 90 & 0.0989 & 466,136 & 56.1 & 255,285 & 239,773 & 66,573 \\
\hline Grid/PV/WT & 62 & 12 & 43 & 0.0726 & 274,310 & 60.6 & 200,772 & 192,143 & 47,795 \\
\hline
\end{tabular}

\subsubsection{Discussion Results}

It is clear from the previous results that the integration of $\mathrm{PV}$ array to the main grid has the lowest cost of production for all four locations comparing with other configurations. In Tables 4 to 7, a solar array can generate more than $50 \%$ of total energy while the main grid shares the rest of the load demand. The main grid substitutes energy storage which can minimize the cost of production and improve the reliability of the system. The simulation results show that the developed Grid/PV configuration Al Baha Universities has the lowest $\mathrm{COE}$ and $\mathrm{CO}_{2}$ emission among other universities due to high solar radiation availability. The simulation results validate the results from collected meteorological data in section 2 in this study. Moreover, the modeling results prove that $\mathrm{Al}$ Baha University in the southern region of KSA has the highest solar radiation and lower COE which confirms the involved results in the aforementioned literature review. In general, the cost of energy of Grid/PV configuration is considered as lower than Gridonly systems. It is worth to mention that the developed HRES-only systems in Table 8 can cover the load demand in a case of stand-alone mode of the grid. Among all considered locations, Al Baha University has the renewable energy potential to meet the load demand for HRES-only sys- tems with the minimum COE of $0.433 \$ / \mathrm{kWh}$. The high COE of the stand-alone systems comparing with the grid's cost is due to expensive energy storage components as shown in Table 8.

\subsubsection{Environmental Results}

The detailed pollutant emissions of most of the possible configurations are listed in Table 9. The grid-only system shows high emissions comparing with other configurations. For example, carbon monoxide for the grid-only system is higher than Grid/PV and Grid/WT systems for all selected locations. The factor of RF plays a significant role in reducing harmful emissions. Taking sulphur dioxide emission as an example, the developed Grid/PV system at $\mathrm{Al}$ Baha University ( $59.1 \%$ of $\mathrm{RF}$ ) has the lowest value compared with other systems. Besides, the developed Grid/WT system at Tabuk University shows lower nitrogen oxide emissions comparing with other Grid/WT systems because of high wind speed in the northern region of KSA. The proposed Grid/PV configuration can reduce carbon dioxide $\left(\mathrm{CO}_{2}\right)$ emission for Al Baha University, University of Jeddah, Sattam University, and Tabuk University by $54.3 \%$,

Table 8: Optimization results of HRES-only systems for selected Universities.

\begin{tabular}{llccccccc}
\hline University & PV $(\mathrm{kW})$ & WT(kW) & AC/DC(kW) & Batt.(kW) & COE $(\$ / k W h)$ & NPC $(\$)$ & Prod.(kWh/y) & Cons.(kWh/y) \\
\hline Al Baha & 223 & 82 & 66 & 478 & 0.433 & $1,489,393$ & 474,761 & 175,134 \\
Jeddah & 260 & 96 & 60 & 455 & 0.459 & $1,580,394$ & 542,393 & 175,176 \\
Sattam & 409 & 162 & 70 & 438 & 0.560 & $1,928,734$ & 829,621 & 175,168 \\
Tabuk & 339 & 90 & 69 & 466 & 0.497 & $1,711,927$ & 706,958 & 175,192 \\
\hline
\end{tabular}

Table 9: Detailed environmental results for selected universities.

\begin{tabular}{|c|c|c|c|c|c|c|c|c|c|}
\hline \multicolumn{10}{|l|}{ Emissions (kg/year) } \\
\hline & \multirow[b]{2}{*}{ Grid-only } & \multicolumn{2}{|l|}{ Al Baha } & \multicolumn{2}{|l|}{ Jeddah } & \multicolumn{2}{|l|}{ Sattam } & \multicolumn{2}{|l|}{ Tabuk } \\
\hline & & Grid/PV & Grid/WT & Grid/PV & Grid/WT & Grid/PV & Grid/WT & Grid/PV & Grid/WT \\
\hline Carbon dioxide & 110,726 & 50,588 & 80,975 & 52,183 & 78,597 & 58,060 & 72,820 & 53,981 & 66,573 \\
\hline Carbon monoxide & 314 & 143 & 229 & 148 & 223 & 164 & 206 & 153 & 189 \\
\hline Unburned hydrocarbon & 35 & 16 & 25.6 & 16.5 & 24.9 & 18.4 & 23 & 17.1 & 21.1 \\
\hline Particulate matter & 23.7 & 10.8 & 18.3 & 11.3 & 17.4 & 12.9 & 16.1 & 12 & 14.7 \\
\hline Sulphur dioxide & 258 & 118 & 188 & 121 & 183 & 135 & 169 & 126 & 155 \\
\hline Nitrogen oxides & 2,803 & 1,281 & 2,050 & 1,321 & 1,990 & 1,470 & 1,844 & 1,367 & 1,685 \\
\hline
\end{tabular}


$52.9 \%, 47.6 \%$, and $51.3 \%$, respectively comparing with the grid-only system.

\subsubsection{Comparison Results}

It is essential to compare the current results with previously reviewed studies from other Arabian Gulf countries. Table 3 lists a major study for university buildings using different studied systems. These include a range of systems such as off-grid and grid-connected models, PV, WT, battery banks, fuel cells, and diesel generator. In this regard, Al Baha University provides lower COE comparing with other universities because of higher solar radiation. Besides, University of Sharjah and Islamic Azad University show a better percentage of RF with $66.1 \%$ and $100 \%$, respectively. The greenhouse emissions $\left(\mathrm{CO}_{2}\right)$ depend on the integration of energy from renewable resources as can be seen from Table 3. It is worth mentioning that the proposed procedure can be used at any university around the world.

\subsection{Sensitivity Analysis}

Sensitivity analysis is important to validate the proposed system. A Grid/PV system is used since it provides a minimum COE and NPC comparing with other case studies. The proposed system is applied for sensitivity analysis for the selected universities based on the following categories:

1. Effect of tariff variation.

2. Payback period.

3. Effect of load demand variation.

\subsubsection{Effect of Tariff Variation}

Since the electricity tariff is varied based on the changing on the fossil fuel price, the tariff is expected to be changed. The current tariff of electricity price from the main grid is $0.085 \$ / \mathrm{kWh}$. The comparison of NPC for the Grid-only system with the Grid/PV model for all selected universities is addressed in Figure 12. It is assumed that the current tariff is changed from $0.085 \$ / \mathrm{kWh}$ to $0.2 \$ / \mathrm{kWh}$. It can be seen from Figure 12 that the variation of electricity tariff has a major impact on the NPC with the Grid-only system. The reason is that the proposed configurations of Grid/PV for all selected universities offer more than $50 \%$ of RF. For example, the tariff's variation has a lower impact on the proposed Grid/PV system ( $56.7 \%$ of RF) at University of Jeddah comparing with the grid-only system. Figure 12 addresses that NPC of grid-only at tariff of $0.2 \$ / \mathrm{kWh}$ equals 688,803 $\$$ while NPC of Grid/PV system is 419,187 \$. The tariff's variation has a small impact on NPC when RF is increased. Hence, the proposed Grid/PV configurations provide better NPC with tariff variation comparing with grid-only systems.

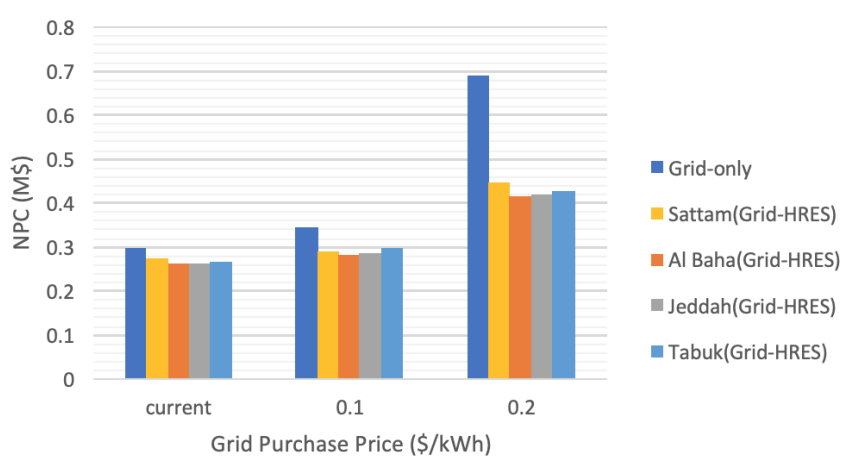

Figure 12: Comparison of tariff variation effect on total NPC.

\subsubsection{Payback Period}

The considered Grid/PV system is used to calculate the payback period comparing with the Grid-only system. The economic analysis is implemented to $\mathrm{Al}$ Baha University to investigate the payback period. It is assumed that electricity tariff is varied in order to address different situations. The simulation results compare the Grid/PV system with grid-only system to estimate the payback year. Figure 13 shows the payback period of Grid/PV system for Al Baha University. The payback point occurs after 17 years at the

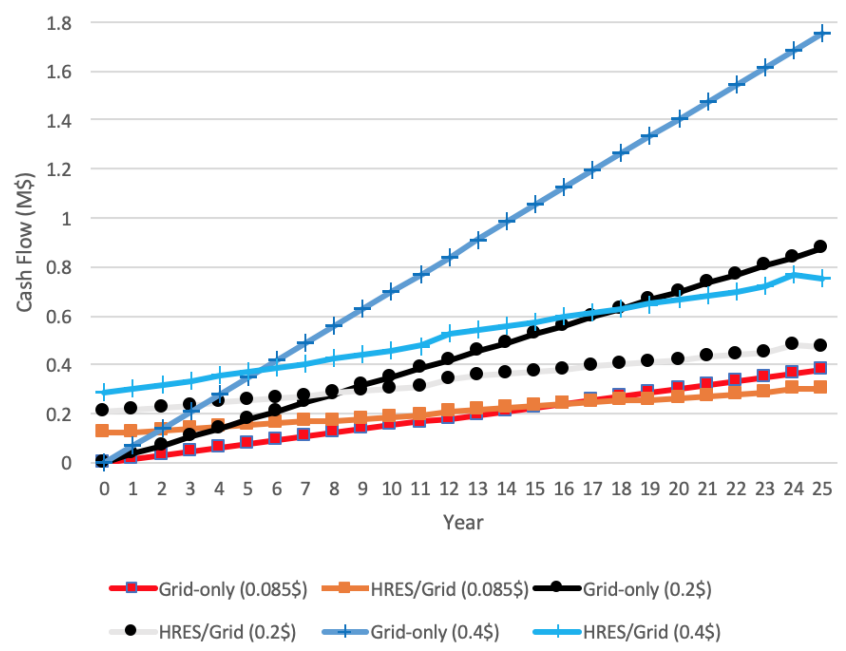

Figure 13: Payback period of grid's tariff for Al Baha University. 
current tariff while it decreases when the tariff is increased. Moreover, the proposed Grid/PV system shows superior revenue when the tariff is increased. The reason is that the economic cost of a PV array is fixed while the cost of the grid depends on the tariff variation.

\subsubsection{Effect of Load Demand Variation}

The selected universities are emerging universities. So, the load demand is expected to increase due to labs and classrooms increment. The average daily load demand is varied from $10 \mathrm{kWh} /$ day to $40 \mathrm{kWh} /$ day. So, the annual load demand will increase from $87,471 \mathrm{kWh} /$ year to 350,400 $\mathrm{kWh} /$ year. The impact of annual load demand increasing on NPC is provided in Figure 14. The NPC is changed with the changing of load demand. Also, NPC of the proposed Grid/PV systems for all selected universities has a direct correlation with the load demand variations. So, the proposed Grid/PV system can meet the load demand with the variation of load demand.

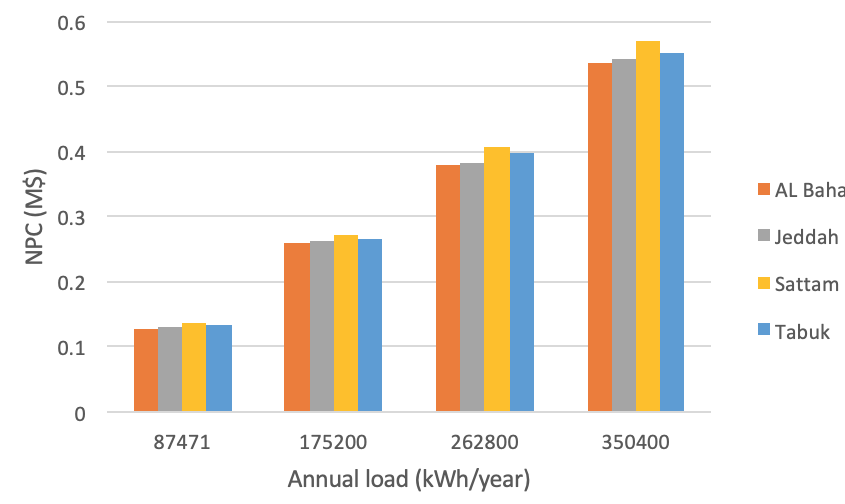

Figure 14: Load demand changing for selected universities.

\section{Conclusions}

The potential of power generation from renewable energy and the conventional grid is investigated at different universities in the Kingdom of Saudi Arabia. The meteorological data are analyzed by considering solar radiation, wind speed, and temperature in various regions in Saudi Arabia. The mathematical and economic equations for the proposed system are also presented in this study. Five different configurations have been examined at autonomous and grid-connected modes using computer-aided HOMER
Software. The studied systems include conventional grid, PV array, wind turbines, battery storage, or a combination of hybrid configurations.

Five examined systems are simulated for each selected university to cover most of the solar and wind renewable energy potentials in Saudi Arabia. The desired universities are Al Baha University (southern province), Sattam University (eastern province), University of Jeddah (western province), and Tabuk University (northern province). The simulation results present that the proposed Grid/PV configurations generate a lower cost of energy (COE) for all selected locations comparing with other configurations. It is addressed in this study that the southern region of Saudi Arabia has higher renewable resources potential which is reflected in the COE at Al Baha University with 0.0688 $\$ / \mathrm{kWh}$. In the simulation results, the Grid/PV configuration provides more than $50 \%$ from renewable resources at all selected locations which leads to lower $\mathrm{CO}_{2}$. The environmental analysis shows that the percentage of RF impact on the harmful emissions from fossil fuels.

Sensitivity analysis showed that Grid/PV systems will become more competitive with increasing electricity tariff and cost. At the present 2020 tariff of electricity, the proposed Grid/PV configuration has a lower COE than the Grid-only system for all selected universities. For a 25year project period, Grid/PV system at Al Baha University provides a payback time of 16 years at the current tariff while it decreases dramatically when the cost of electricity is increased. The proposed Grid/PV system can achieve the load demand at different load variation. Overall, the findings reveal that harvesting energy from renewable resources become competitive with fossil fuel's energy due to financial and environmental advantages. The solar energy provides a promising potential for educational buildings, or even residential sectors, at current and future energy consumption of KSA. The developed approach can be used for other university buildings in Saudi Arabia or around the world where meteorological and load data exist.

\section{References}

[1] World Development Indicator [Internet]. DataBank; c2020 [cited 2020 February 12]. Available from: https://databank.worldbank. org/source/world-development-indicators

[2] Middle East Economic Survey. Saudis Slash Subsidies as Oil Revenue Collapses. Volume 59, Issue 1.8 January 2016.

[3] KAPSARC [Internet]. Electricity Consumption by Sectors; [cited 2020 February 13]. Available from: https://datasource.kaps arc.org/explore/dataset/electricity-consumption-by-sectors/ 
[4] Statistical BP. Review of World Energy [Internet]. BP; c2020. [cited 15 August 2020]. Available from: https://www.bp.com

[5] Esmaeil KK, Alshitawi MS, Almasri RA. Analysis of energy consumption pattern in Saudi Arabia's residential buildings with specific reference to Qassim region. Energy Effic. 2019 Dec;12(8):2123-45.

[6] Solar resource maps of Saudi Arabia [Internet]. SOLAR-GIS; c2020 [cited 2020 February 12]. Available from: https://solargis. com/maps-and-gis-data/download/saudi-arabia

[7] Saudi Arabia Renewable Resource Atlas [Internet]. RRATLAS; c2020 [cited 2020 February 10]. Available from: https://rratl as.energy.gov.sa/RRMMPublicPortal/

[8] Maleki A. Design and optimization of autonomous solar-windreverse osmosis desalination systems coupling battery and hydrogen energy storage by an improved bee algorithm. Desalination. 2018 Jun;435:221-34.

[9] Tazay AF, Ibrahim AM, Noureldeen O, Hamdan I. Modeling, Control, and Performance Evaluation of Grid-Tied Hybrid PV/Wind Power Generation System: Case Study of Gabel El-Zeit Region, Egypt. IEEE Access. 2020 May 11.

[10] Zell E, Gasim S, Wilcox S, Katamoura S, Stoffel T, Shibli H, et al. Assessment of solar radiation resources in Saudi Arabia. Sol Energy. 2015 Sep;119:422-38.

[11] Alharbi F, Csala D. Saudi Arabia's solar and wind energy penetration: future performance and requirements. Energies. 2020 Jan;13(3):588.

[12] Ramli MA, Twaha S, Al-Hamouz Z. Analyzing the potential and progress of distributed generation applications in Saudi Arabia: the case of solar and wind resources. Renew Sustain Energy Rev. 2017 Apr;70:287-97.

[13] Razmjoo A, Shirmohammadi R, Davarpanah A, Pourfayaz F, Aslani A. Stand-alone hybrid energy systems for remote area power generation. Energy Rep. 2019 Nov;5:231-41.

[14] Hossain M, Mekhilef S, Olatomiwa L. Performance evaluation of a stand-alone PV-wind-diesel-battery hybrid system feasible for a large resort center in South China Sea, Malaysia. Sustain Cities Soc. 2017 Jan;28:358-66.

[15] Olatomiwa L, Mekhilef S, Ismail MS, Moghavvemi M. Energy management strategies in hybrid renewable energy systems: A review. Renew Sustain Energy Rev. 2016 Sep;62:821-35.

[16] Razmjoo A, Ehyaei MA, Ahmadi A, Pazhoohesh M, Marzband M, Mansouri Khosravi M, et al. Implementation of energy sustainability using hybrid power systems, a case study. Energy Sources

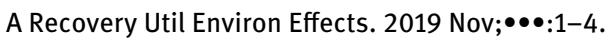

[17] Olatomiwa L, Mekhilef S, Huda AS, Ohunakin OS. Economic evaluation of hybrid energy systems for rural electrification in six geo-political zones of Nigeria. Renew Energy. 2015 Nov;83:43546.

[18] Razmjoo AA, Davarpanah A, zargarian A. The role of renewable energy to achieve energy sustainability in Iran. An economic and technical analysis of the hybrid power system. Technology and Economics of Smart Grids and Sustainable Energy. 2019 Dec;4(1):7.

[19] Al-Sharafi A, Sahin AZ, Ayar T, Yilbas BS. Techno-economic analysis and optimization of solar and wind energy systems for power generation and hydrogen production in Saudi Arabia. Renew Sustain Energy Rev. 2017 Mar;69:33-49.

[20] Ramli MA, Hiendro A, Al-Turki YA. Techno-economic energy analysis of wind/solar hybrid system: case study for western coastal area of Saudi Arabia. Renew Energy. 2016 Jun;91:374-85.
[21] Krishna LV, Al Thalhi FA. Solar and wind energy potential in the Tabuk region, Saudi Arabia. Int J Appl Sci Technol. 2015 Jun;5(3).

[22] Tazay AF, Samy MM, Barakat S. A Techno-Economic Feasibility Analysis of an Autonomous Hybrid Renewable Energy Sources for University Building at Saudi Arabia. J Electr Eng Technol. 2020

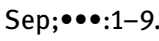

[23] Leal Filho W, Salvia AL, Do Paco A, Anholon R, Quelhas OL, Rampasso IS, et al. A comparative study of approaches towards energy efficiency and renewable energy use at higher education institutions. J Clean Prod. 2019 Nov;237:117728.

[24] Amran YA, Amran YM, Alyousef R, Alabduljabbar H. Renewable and sustainable energy production in Saudi Arabia according to Saudi Vision 2030; Current status and future prospects. J Clean Prod. 2020 Feb;247:119602.

[25] Renewables 2016 Global Status Report REN21. REN21; c2016. [cited 2020 February 10]. Available from: https://www.ren21. net/about-us/annual-reports/

[26] Armin Razmjoo A, Sumper A, Davarpanah A. Energy sustainability analysis based on SDGs for developing countries. Energy Sources A Recovery Util Environ Effects. 2020 May;42(9):104156.

[27] Al-Sharafi A, Sahin AZ, Ayar T, Yilbas BS. Techno-economic analysis and optimization of solar and wind energy systems for power generation and hydrogen production in Saudi Arabia. Renew Sustain Energy Rev. 2017 Mar;69:33-49.

[28] Ghenai C, Bettayeb M. Modelling and performance analysis of a stand-alone hybrid solar PV/Fuel Cell/Diesel Generator power system for university building. Energy. 2019 Mar;171:180-9.

[29] Ghenai C, Bettayeb M. Grid-tied solar PV/fuel cell hybrid power system for university building. Energy Procedia. 2019 Feb;159:96-103.

[30] Fazelpour F, Soltani N. Feasibility study of renewable energy resources and optimization of electrical hybrid energy systems: Case study for Islamic Azad University, South Tehran Branch, Iran. Therm Sci. 2017;21 1 Part A:335-51.

[31] Atmospheric Science Data Center[Internet]. NASA Langley Research Center; c2020 [cited 2020 February 30]. Available from: https://eosweb.larc.nasa.gov

[32] Abushnaf J, Rassau A. Impact of energy management system on the sizing of a grid-connected PV/Battery system. Electr J. 2018 Mar;31(2):58-66.

[33] Mosaad MI, El-Raouf MO, Al-Ahmar MA, Bendary FM. Optimal PI controller of DVR to enhance the performance of hybrid power system feeding a remote area in Egypt. Sustain Cities Soc. 2019 May;47:101469.

[34] Anoune K, Laknizi A, Bouya M, Astito A, Abdellah AB. Sizing a PVWind based hybrid system using deterministic approach. Energy Convers Manage. 2018 Aug;169:137-48.

[35] Charrouf O, Betka A, Becherif M, Tabanjat A. Techno-economic analysis of wind turbines in Algeria. International Journal of Emerging Electric Power Systems. 2018 Feb;19(1). https://doi.org/10.1515/ijeeps-2017-0178.

[36] Diaf S, Diaf D, Belhamel M, Haddadi M, Louche A. A methodology for optimal sizing of autonomous hybrid PV/wind system. Energy Policy. 2007 Nov;35(11):5708-18.

[37] Ding F, Li P, Huang B, Gao F, Ding C, Wang C. Modeling and simulation of grid-connected hybrid photovoltaic/battery distributed generation system. InCICED 2010 Proceedings 2010 Sep 13 (pp. 1-10). IEEE. 
[38] Demirbas A, Hashem AA, Bakhsh AA. The cost analysis of electric power generation in Saudi Arabia. Energy Sources B Econ Plan Policy. 2017 Jun;12(6):591-6.

[39] Consumption Tariffs [Internet]. Saudi Electric Company; c2020 [cited 2020 April 5]. Available from: https://www.se.com.sa/enus/customers/Pages/TariffRates.aspx

[40] Rezzouk H, Mellit A. Feasibility study and sensitivity analysis of a stand-alone photovoltaic-diesel-battery hybrid energy system in the north of Algeria. Renew Sustain Energy Rev. 2015 Mar;43:1134-50.

[41] Islam MS. A techno-economic feasibility analysis of hybrid renewable energy supply options for a grid-connected large office building in southeastern part of France. Sustain Cities Soc. 2018 Apr;38:492-508.

[42] Hybrid Optimization Model for Multiple Energy Resources [Internet]. HOMERENERGY; c2020 [cited 2020 January 16]. Available from: https://www.homerenergy.com/
[43] Amutha WM, Rajini V. Cost benefit and technical analysis of rural electrification alternatives in southern India using HOMER. Renew Sustain Energy Rev. 2016 Sep;62:236-46.

[44] Photovoltaic Modules Specification Sheet [Internet]. Mitsubishi Electric Photovoltaic Module; c2020 [cited 2020 April 2]. Available from: https://www.mitsubishielectricsolar.com

[45] Wind Turbine Specification Sheet [Internet]. THY WindPower; c2020 [cited 2020 April 2]. Available from: http://www.folke center.eu/PDF/Preview-Catalogue-Small-Wind-Turbines.pdf

[46] Battery Data Sheet[Internet]. Torjan Battery Company; c2020 [cited 2020 April 1]. Available from: https://www.trojanbatt ery.com

[47] Three Phase Inverter Data Sheet [Internet]. SolarEdge; c2020 [cited 2020 April 4]. Available from: https://www.solaredge.c $\mathrm{om} / \mathrm{sites} /$ default/files/se-three-phase-inverter-datasheet.pdf 


\section{A Appendix}

\section{A.1 Photovoltaic Data}

The model of PV cell is obtained from Mitsubishi Electric company. The series of the PV is MLE260HD. The cell type is Mono-Si. The output power from each cell is $260 \mathrm{~W}$. Each designed PV array could provide $10 \mathrm{~kW}$ at the appropriate operation condition. Table A10 shows the data of the selected PV array [44].

Table A10: PV data and characteristics.

\begin{tabular}{lcccc}
\hline Cell No. & $\mathbf{P}_{m p}(\mathrm{~W})$ & $\mathbf{V}_{m p}(\mathrm{~V})$ & $\mathbf{I}_{m p}(\mathrm{~A})$ & $\mathrm{NOCT}(\mathrm{C})$ \\
\hline 120 & 260 & 31.4 & 8.29 & 45.7 \\
\hline
\end{tabular}

\section{A.2 Wind Turbine Data}

The model of WT is obtained from THY WindPwer company. The type of WT is TWP-40-10KW. The rated output power is $10 \mathrm{~kW}$ while the peak power is $11 \mathrm{~kW}$. The operational mode the selected WT is grid-connected application where the installed generator is asynchronous induction. The datasheet of the horizontal WT is given in Table A11 [45].

Table A11: WT data and characteristics.

\begin{tabular}{lccc}
\hline $\mathbf{P}_{r}(\mathrm{~kW})$ & $\mathbf{V}(\mathrm{A})$ & Wind $_{\text {cutin }}(\mathrm{m} / \mathrm{s})$ & Wind $_{\text {cutout }}(\mathrm{m} / \mathrm{s})$ \\
\hline 10 & 230 & 3.5 & 25 \\
\hline
\end{tabular}

\section{A.3 Battery Data}

A lead acid battery is used as a storage of the system. SIND 06-920 (trojan) model battery with 12 lifetime years is selected in this paper. The detailed characteristics of the battery storage are given in Table A12 [46].

Table A12: Battery data and characteristics.

\begin{tabular}{lccc}
\hline Type & Capacity (Ah) & V (v) & Energy (kWh) \\
\hline Advanced lead acid & $920 @ 100 \mathrm{hr}$ & 6 & 5.52 \\
\hline
\end{tabular}

\section{A.4 DC/AC Converter Data}

The three-phase converter is selected from Solaredge manufacture. The converter has a high-performance warranty with approximately 12 years. The datasheet and characteristics of the considered DC/AC converter are given in Table A13 [47].

Table A13: DC/AC converter data and characteristics.

\begin{tabular}{lccccr}
\hline Type & $\mathbf{P}_{\text {out }}(\mathrm{kW})$ & $\mathbf{V}_{\text {out }}(\mathrm{v})$ & $\mathbf{F}(\mathrm{Hz})$ & $\mathbf{V}_{\max }(\mathrm{v})$ & Eff.(\%) \\
\hline SE3K & 3 & 230 & $50 / 60$ & 750 & 98 \\
\hline
\end{tabular}

